adw. dr Piotr Sobański LL.M. (Zielona Góra)

piotr.sobanski@adwokatura.pl

\title{
Wybrane aspekty prawne tzw. landyzacji Polski
}

\section{Uwagi wstępne}

Podstawą do rozważań na temat tzw. landyzacji jest treść 21 Tez Samorządowych z dnia 4 czerwca 2019 r. ${ }^{1}$. Ten temat jest aktualny, gdyż wśród społeczeństwa od pewnego czasu istnieją obawy przed zjawiskiem landyzacji ${ }^{2}$. W tym kontekście landyzację należy postrzegać jako proces stopniowego przeobrażania Polski w państwo federalne, jakim jest m.in. RFN ${ }^{3}$.

Dnia 4 czerwca 2019 r., podczas obchodów Święta Wolności i Solidarności w Gdańsku, rozpoczęły się rozmowy na temat przyszłości polskich miast i wsi, w których brało udział ponad 300 wójtów, burmistrzów, starostów, prezydentów i marszałków. Wynikiem ustaleń była deklaracja zawierająca 21 Tez. Tezy zostały zaprezentowane jako postulaty Samorządnej Rzeczpospolitej dnia 31 sierpnia 2019 r. podczas debaty „Przyszłość samorządu” w Europejskim Centrum Solidarności w Gdańsku. Samorządna Rzeczpospolita zadeklarowała przygotowanie na ich podstawie projektów ustaw, które złoży pod obrady Parlamentu RP ${ }^{4}$. Deklaracja z dnia 4 czerwca 2019 r. była apelem o decentralizację państwa i punktem wyjścia do wprowadzenia rozwiązań wzmacniających lokalną samorządność5.

Przeprowadzona w niniejszym artykule analiza postulatów Samorządnej Rzeczypospolitej opiera się głównie na Konstytucji RP i Europejskiej Karcie Samorządu Lokalnego, gdyż Preambuła do Tez zawiera żądanie „zapewnienia możliwości rozwoju (...) miast i gmin zgodnie z Konstytucją RP i Europejską Kartą Samorządu Lokalnego"“.

1 Z wszystkimi Tezami oraz ich uzasadnieniami można zapoznać się na stronie http://www.czestochowa.pl/data/newsFiles/21_tez_samorzadowych_gdansk_4czerwca201.pdf (data dostępu 10 stycznia 2020 r.).

2 Por. m.in.: P. Lewandowski, Tylko u nas! To się dzieje. Trwa pełzające rozbicie dzielnicowe https://polskaniepodlegla.pl/opinie/item/20467-tylko-u-nas-to-sie-dzieje-trwa-pelzajace-rozbicie-

dzielnicowe (data dostępu: 5 stycznia 2020 r.); M. Rachoń, Więcej kasy w ręce ludzi Platformy, nawet kosztem likwidacji państwa https://niezalezna.pl/283355-wiecej-kasy-w-rece-ludzi-platformy-nawetkosztem-likwidacji-panstwa (data dostępu: 7 stycznia 2020 r.); Piąty rozbiór Polski - Janecki o planach demontażu RP https://www.wsieciprawdy.pl/piaty-rozbior-polski-janecki-o-planach-demontazu-rp-pnews3388.html (data dostępu: 10 listopada 2019 r.); Landyzacja w praktyce. Polscy samorządowcy realizują niemiecki projekt dla Szczecina?! RP https://polskaniepodlegla.pl/kraj-swiat/item/20562-landyzacja-wpraktyce-polscy-samorzadowcy-realizuja-niemiecki-projekt-dla-szczecina (data dostępu: 10 listopada 2019 r.).

3 Szerzej na temat ustroju federalnego: H. Kilper, R. Lhotta, Föderalismus in der Bundesrepublik Deutschland: Eine Einführung, Springer Verlag, Wiesbaden 1996, s. 26 i n.; R. A. Lorz, Interorganrespekt im Verfassungsrecht: Funktionenzuordnung, Rücksichtnahmegebote und Kooperationsverpflichthungen: eine rechtsvergleichende Analyse anhand der Verfassungssysteme der Bundesrepublik Deutschland, der Europäischen Union und der Vereinigten Staaten, Mohr Siebeck, Tübingen 2001, s. 595 i n.

4 https://www.samorzadydlapolski.pl/ (data dostępu: 5 listopada 2019 r.).

5 http://www.czestochowa.pl/page/pdf.php?str=7\&id=12576 (data dostępu: 11 stycznia 2019 r.).

6 Treść Preambuły brzmi następująco:

„30 lat temu odbyły się pierwsze po II Wojnie Światowej częściowo wolne wybory parlamentarne, a rok później rozpoczęła się budowa Polski samorządowej. Demokracja na szczeblu lokalnym zyskała realny wymiar.

Niestety w ostatnich latach obserwujemy działania mające na celu centralizację państwa $i$ ograniczenie roli wspólnot lokalnych. Dlatego, reprezentując naszych mieszkańców, żądamy zapewnienia możliwości rozwoju naszych miast i gmin zgodnie z Konstytucją RP i Europejską Kartą Samorządu Lokalnego. 
Rozważania odnoszą się głównie do Tez opatrzonych następującymi numerami: 1, 3, 5, 14, 17. Należy mieć jednak na uwadze, że na podstawie 21 Tez Samorządowych traktowanych jako całość, a nie na podstawie wybranych Tez, planowano zmianę obowiązujących przepisów.

\section{Zagadnienie jednolitości Polski i decentralizacji w świetle Konstytucji}

Jak stanowi art. 3. Konstytucji Rzeczypospolitej Polskiej, Polska jest państwem jednolitym ${ }^{7}$. Zasada jednolitości, zwana także zasadą unitaryzmu, wskazuje na jednorodny charakter Polski, który istnieje w zakresie struktury terytorialnej, systemu prawa oraz struktury społeczno-politycznej ${ }^{8}$. Określona wprost w art. 3 Konstytucji RP jednolitość terytorialna i ustrojowa Polski wyraźnie wyklucza federacyjny ustrój państwa, a także autonomie terytorialne ${ }^{9}$.

Zgodnie z art. 15 ust. 1 Konstytucji, ustrój terytorialny Polski zapewnia wprawdzie decentralizację władzy publicznej, lecz zasada jednolitości państwa wyznacza granicę zasady decentralizacji ${ }^{10}$. Niecentralistyczna administracja państwowa oraz scentralizowana administracja rządowa są zatem jednolite przy poszanowaniu odrębności obu sektorów ${ }^{11}$.

Jak wynika z art. 16 ust. 2 Konstytucji, samorząd terytorialny uczestniczy w sprawowaniu władzy publicznej, a przysługującą mu w ramach ustaw istotną część zadań publicznych wykonuje w imieniu własnym i na własną odpowiedzialność ${ }^{12}$. Z unormowań zawartych w Konstytucji wynikają trzy podstawowe zasady, które odnoszą się do funkcjonowania samorządu terytorialnego. Są to: zasada pomocniczości, zasada samodzielności i zasada domniemania właściwości samorządu terytorialnego ${ }^{13}$. Należy mieć też na uwadze, że celem działania samorządu jest odpowiedzialność za sprawy, które bezpośrednio dotyczą lokalnych społeczności i mieszkańców ${ }^{14}$. S. Patyra trafnie zauważa, że właśnie w funkcjonowaniu wspólnot lokalnych najpełniej realizuje się

Przedstawiamy 21 tez, które - po konsultacjach z mieszkańcami, sektorem pozarządowym $i$ całym środowiskiem samorządowym - zaprezentujemy 31 sierpnia jako postulaty Samorządnej Rzeczpospolitej.

Na ich podstawie przygotujemy projekty ustaw, które złożymy pod obrady nowego parlamentu RP

Będziemy dążyć do tego, aby nasze miasta i gminy, w 2020 roku, 30 lat od pierwszych w pełni demokratycznych wyborów samorządowych, uzyskały prawodawstwo godne demokratycznej Polski w Europie.

Chcemy Polski samorządnej i solidarnej, w której mieszkańcy sami decydują o losach swoich lokalnych wspólnot".

7 Konstytucja Rzeczypospolitej Polskiej z dnia 2 kwietnia 1997 r., Dz.U z 1997 r., Nr 78, poz. 483.

8 G. Kościelniak, Zmiany społeczne, gospodarcze $i$ kulturowe $w$ erze ponowoczesnej a ustrojowa przyszłość instytucji samorządu terytorialnego w Polsce, Państwo i Społeczeństwo, Nr 3, 2012, s. 25.

9 J. Korczak, Współdziałanie organów administracji rządowej i samorządowej w stanach nadzwyczajnych, LEX Nr 313966/2.

10 G. Kościelniak, op. cit., s. 25; S. Patyra, Zakres dopuszczalnej ingerencji władzy centralnej w sferę funkcjonowania samorządu terytorialnego w Polsce - refleksje aksjologiczne [w:] Samorządy w procesie decentralizacji władzy publicznej, M. Chrzanowski, J. Sobczak (red.), Wydawnictwo Muzyczne POLIHYMNIA, Lublin 2017, s. 26.

11 J. Korczak, op. cit.

12 A. Doliwa, Konstytucjonalizacja osobowości prawnej jako podstawa współpracy międzynarodowej gmin, Białostockie Studia Prawnicze, Vol. 12, 2012, s. 211.

13 Szerzej: P. Antkowiak, Decentralizacja władzy publicznej w Polsce, Środkowoeuropejskie Studia Polityczne, Nr 2, 2012, s. 168.

14 Por.: J. Buzek, Samorządna Rzeczpospolita - 25 lat samorządu w Polsce, Ruch Prawniczy, Ekonomiczny i Socjologiczny, Zeszyt 3, 2015, s. 12. 
wyrażona w art. 4 Konstytucji idea suwerennej władzy Narodu ${ }^{15}$.

Nie tylko administracja państwowa i rządowa, ale także administracja samorządowa charakteryzuje się jednolitością, oczywiście przy poszanowaniu jej odrębności wobec pozostałych dwóch sektorów ${ }^{16}$. Zasada jednolitości kształtuje pozycję ustrojową samorządu terytorialnego. Zasada jednolitości wyznacza zarazem granicę zasady decentralizacji, pełniąc rolę hamulca przed przekształceniem samorządu terytorialnego w autonomię terytorialną ${ }^{17}$.

O ile samorząd terytorialny jest kategorią obiektywną i niezależną od woli prawodawcy, to jego istnienie jest kształtowane przez poszanowanie dobra wspólnego ${ }^{18}$. Zgodnie bowiem z treścią art. 1 Konstytucji Polska jest dobrem wspólnym wszystkich obywateli. Zasada dobra wspólnego dotychczas nie doczekała się definicji legalnej ${ }^{19}$. W. Łączkowski trafnie zauważa, że dobro wspólne zalicza się do jednej z podstawowych zasad życia społecznego, która powinna służyć całej wspólnocie, a także poszczególnym jej członkom. Dobro wspólne jest zatem równocześnie wartością zbiorową i indywidualną ${ }^{20}$.

O zadaniach poszczególnych kategorii samorządu terytorialnego przesądza wola ustawodawcy $^{21}$. Jednostki samorządu terytorialnego nie mają uprawnień władzy ustawodawczej, a podejmowane przez nie akty administracyjne o charakterze zarówno generalnym, jak i indywidualnym, muszą mieć umocowanie w Konstytucji i ustawach ${ }^{22}$. Tym samym zakres kompetencji samorządu terytorialnego jest faktycznie uzależniony od Parlamentu ${ }^{23}$.

P. Radziewicz zauważa, że z art. 15 ust. 2 Konstytucji wynika, iż ustalanie znaczenia zasady decentralizacji w danej dziedzinie życia społecznego, będącej przedmiotem regulacji ustawowych, a także przyjęcie szczegółowych rozwiązań normatywnych w tym zakresie, należy do kompetencji ustawodawcy zwykłego ${ }^{24}$. W tym kontekście trzeba jeszcze raz podkreślić, że zasada decentralizacji jest wyraźnie ograniczona przez określoną w art. 3 Konstytucji zasady jednolitości państwa.

Reasumując, zasadę dobra wspólnego pozostającą $w$ harmonii $z$ zasadą jednolitości państwa powinno się traktować jako czynniki uniemożliwiające dokonanie tzw. landyzacji Polski bez diametralnej zmiany Konstytucji.

Preambuła do Tez zawiera żądanie „zapewnienia możliwości rozwoju (...) miast $i$ gmin zgodnie z Konstytucją RP. W Polsce istnieje szereg unormowań odnoszących się do samorządu terytorialnego. Skoro z treści Preambuły wydaje się wynikać, jakoby obowiązujące regulacje cechowały się brakiem ich zgodności z Konstytucją, należy przypomnieć, że w Polsce obowiązuje zasada domniemania konstytucyjności ustaw. Instytucja ta nie została uregulowana w przepisach. Istnieje pierwotne założenie, że

15 S. Patyra, Samorząd terytorialny jako czynnik wzmacniający zasadę dobra wspólnego, Ruch Prawniczy, Ekonomiczny i Socjologiczny, Zeszyt 1, 2018, s. 237.

16 J. Korczak, op. cit.

17 G. Kościelniak, op. cit., s. 25.

18 L. Kieres, Europejska karta samorządu lokalnego w orzecznictwie Trybunału Konstytucyjnego, Ruch Prawniczy, Ekonomiczny i Socjologiczny, Zeszyt 3, 2015, s. 89.

19 S. Patyra, Samorząd..., s. 231.

20 W. Łączkowski, Trójpodział władz a dobro wspólne, Lex nr 339140/1.

21 L. Kieres, Europejska karta samorządu lokalnego w orzecznictwie Trybunału Konstytucyjnego, Ruch Prawniczy, Ekonomiczny i Socjologiczny, Zeszyt 3, 2015, s. 88.

22 G. Kościelniak, op. cit., s. 25.

23 T. Litwin, Pojęcie „przedstawiciela Narodu” w świetle art. 4 ust. 2 Konstytucji RP z 1997 r., Horyzonty Polityki, Vol. 9, s. 25.

24 P. Radziewicz, Decentralizacja jako pojęcie prawne, Kwartalnik Prawa Publicznego, Nr 1-2, 2015, s. 11. 
uchwalane ustawy są zgodne z postanowieniami Konstytucji. Ciężar dowodu spoczywa na podmiocie kwestionującym zgodność ustawy z Konstytucją. Dopóki podmiot ten nie powoła konkretnych i przekonujących argumentów prawnych na poparcie swej tezy, dopóty Trybunał Konstytucyjny uznawać będzie kontrolowane przepisy prawa wewnętrznego za konstytucyjne ${ }^{25}$.

\section{Charakter prawny Europejskiej Karty Samorządu Lokalnego}

Dnia 15 października 1985 r. została sporządzona w Strasburgu Europejska Karta Samorządu Lokalnego, która jest otwarta do podpisu dla państw członkowskich Rady Europy (art. 15 ust. 1 Karty). Karta została przyjęta i ratyfikowana przez szereg państw europejskich, w tym przez Polskę ${ }^{26}$.

W Preambule do Karty podniesiono, że „ochrona i ugruntowanie samorządu terytorialnego w poszczególnych krajach Europy przyczyniają się w poważnym stopniu do budowy Europy w oparciu o zasady demokracji i decentralizacji władzy" oraz przyznano, „że jest to możliwe przy założeniu, że społeczności lokalne wyposażone są w organy decyzyjne ukonstytuowane $w$ sposób demokratyczny $i$ korzystają z szerokiej autonomii odnośnie do kompetencji, sposobów ich wykonywania oraz środków niezbędnych do realizacji ich zadań".

W polskim porządku prawnym istnieje od wielu lat podstawa konstytucyjna i prawna samorządu lokalnego, o której mowa w art. 2 Karty. W myśl art. 4 ust. 1 Karty podstawowe kompetencje społeczności lokalnych zostały określone w Konstytucji i w ustawach. Jeszcze raz należy przy tym podkreślić, że to wola ustrojodawcy i wola ustawodawcy określają sytuację samorządu w państwie. Zgodnie $z$ art. 4 ust. 2 Karty społeczności lokalne mają - w zakresie określonym prawem - pełną swobodę działania w każdej sprawie, która nie jest wyłączona z ich kompetencji lub nie wchodzi w zakres kompetencji innych organów władzy.

W art. 3 Karty została zawarta koncepcja samorządu lokalnego ${ }^{27}$. Od chwili ratyfikacji Karty przez Polskę pojawiały się i pojawiają się nadal propozycje zmian obowiązujących przepisów dotyczących samorządu lokalnego, które uzasadnia się często koniecznością dostosowania polskiego systemu prawa do postanowień Karty ${ }^{28}$. Nie chodzi

25 Szerzej: M. Dąbrowski, Domniemanie zgodności ustaw z Konstytucją Rzeczypospolitej Polskiej z 1997 roku, Katedra Prawa Konstytucyjnego na Wydziale Prawa i Administracji UWM Olsztyn, Olsztyn 2017, s. 73 i n.

26 Dz.U z 1994 r., Nr 124, poz. 607.

27 Art. 3:

„1.Samorząd lokalny oznacza prawo i zdolność społeczności lokalnych, w granicach określonych prawem, do kierowania i zarządzania zasadniczą częścią spraw publicznych na ich własną odpowiedzialność $i$ w interesie ich mieszkańców.

2.Prawo to jest realizowane przez rady lub zgromadzenia, w których skład wchodzą członkowie wybierani w wyborach wolnych, tajnych, równych, bezpośrednich $i$ powszechnych i które mogą dysponować organami wykonawczymi im podlegającymi. Przepis ten nie wyklucza możliwości odwołania się do zgromadzeń obywateli, referendum lub każdej innej formy bezpośredniego uczestnictwa obywateli, jeśli ustawa dopuszcza takie rozwiązanie“.

28 Por. m.in.: M. Mączyński, Reforma ustroju samorządu terytorialnego: uwarunkowania, możliwości $i$ konsekwencje zwiększenia samodzielności JST [w:] Sprawne państwo. Propozycje zmian w funkcjonowaniu jednostek samorządu terytorialnego w Polsce, P. Kopyciński (red.), Uniwersytet Ekonomiczny w Krakowie, Kraków 2015, s. 30 i n.; K. Buczyński, J. Jaworski, P. Sosnowski, Bariery rozwoju samorządu terytorialnego w Polsce z perspektywy 25 lat jego funkcjonowania [w:] Bariery, wyzwania i perspektywy przekształceń samorządu terytorialnego w Polsce, S. Sagan, M. Sitek (red.), Wydawnictwo Wyższej Szkoły Gospodarki Euroregionalnej im. Alcide De Gasperi w Józefowie, Józefów 2016, s. 118 i n. 
jednak o ustosunkowanie się do tego, na ile te koncepcje są słuszne, na ile zaś nie. Przede wszystkim pojawia się bowiem zasadnicze pytanie, w jaki sposób polski ustawodawca jest zobligowany regulacjami zawartymi w Karcie do dokonywania zmian w obowiązujących przepisach. L. Kieres po dokonaniu szczegółowej analizy orzecznictwa Trybunału Konstytucyjnego zauważa, że Trybunał Konstytucyjny nie akceptuje inicjatyw podejmowanych w celu uznania Karty za źródło wzorców w ocenach założeń prawodawczych lub przy weryfikowaniu przyjmowanych przez władze publiczne regulacji prawnych, kiedy mieszczą się one w kategoriach, które są właściwe dla rządzenia ${ }^{29}$. Dokonując oceny charakteru Europejskiej Karty Samorządu Lokalnego należy podnieść, że w świetle orzecznictwa Trybunału Konstytucyjnego nie można domagać się na podstawie Karty zmian ustrojowych w Polsce, polegających na eliminacji zasady jednolitości Polski na rzecz wprowadzenia ustroju federalnego. L. Kieres słusznie zauważa, że zgodności prawa polskiego z Kartą nie podważa odrzucenie przez Konstytucję „koncepcji samorządności terytorialnej wyrażonej przez samodzielność o cechach znamiennych dla autonomii, którą charakteryzuje prawo do przeciwstawiania przez jednostke samorządową własnych interesów państwu jako dobru wspólnemu obywateli". Polski samorząd terytorialny w świetle Konstytucji spełnia przyjęte w Europejskiej Karcie Samorządu Lokalnego warunki dla samorządności ${ }^{30}$. Traktowanie zasady jednolitości Polski jako zagrożenia dla egzystencji samorządu terytorialnego nie jest również zasadne ${ }^{31}$. Ponadto, jak zauważa L. Kieres, Trybunał Konstytucyjny wielokrotnie podkreślał w orzecznictwie, że w Preambule do Karty mowa jest o „szerokiej autonomii", która nie jest tożsama z autonomią pełną ${ }^{32}$.

Warto na marginesie zauważyć, że w orzecznictwie sądów administracyjnych reprezentowane jest stanowisko, iż Europejska Karta Samorządu Lokalnego jest jedynie zbiorem przepisów, które mają charakter postulatywny, wskazujący na pożądane działania sygnatariuszy w celach wskazanych w Preambule do Karty ${ }^{33}$. Analizując treść unormowań zawartych w Karcie, widać wyraźnie, że poszczególne regulacje zawarte w Karcie zostały sformułowane w sposób bardzo ogólny, co czyni niemożliwym ich bezpośrednie stosowanie.

Zatem zawarte w Preambule do 21 Tez żądanie możliwości zapewnienia możliwości rozwoju miast i gmin w sposób, o którym mowa w Tezach nie może być skutecznie dochodzone w oparciu o unormowania zawarte w Europejskiej Karcie Samorządu Lokalnego. Dotyczy to również jakichkolwiek innych postulowanych zmian obowiązujących przepisów, które odnoszą się do zarówno do kształtu jak i kompetencji samorządu terytorialnego w Polsce.

\section{Uwagi krytyczne do Tez Samorządnej Rzeczypospolitej}

W uzasadnieniu Tezy $\mathrm{nr} 5$ pt. „Obowiązek konsultowania z przedstawicielami samorządu i społeczności lokalnej wszystkich projektów ustaw” wskazano, cyt. „Projekty ustaw, szczególnie dotyczące zadań własnych jednostek samorządu terytorialnego, określonych w art. 166 Konstytucji RP, powinny podlegać obowiązkowej konsultacji z zrzeszeniami samorządów jako przedstawicielami wspólnot lokalnych. Wyniki tych

29 L. Kieres, op. cit., s. 84.

30 Szerzej: ibidem, s. 99 i n..

31 G. Kościelniak, op. cit., s. 25.

32 Szerzej: L. Kieres, op. cit., s. 87.

33 Por. m.in.: wyrok WSA w Warszawie z dnia 26 pazdziernika 2006 r, sygn. akt: III SA/Wa 2459/06, LEX nr 276785. 
konsultacji winny być umieszczane w ocenie skutków regulacji każdego projektu ustawy dotyczącej wspólnot lokalnych. Brak uzgodnienia stanowi podstawę do wystąpienia do właściwego sądu".

Wprowadzenie w życie propozycji zawartej w Tezie nr 5 sparaliżowałoby przede wszystkim proces ustawodawczy. Należy zaznaczyć, że w treści Tezy nr 5 zostało zawarte sformułowanie „wszystkich projektów ustaw”, natomiast w krótkim uzasadnieniu do tej Tezy zostało zawarte sformułowanie „Projekty ustaw, szczególnie dotyczące zadań własnych jednostek samorządu terytorialnego", które nie odzwierciedla treści samej Tezy. Trudno ocenić, czy ten zabieg semantyczny był zamierzony, czy przypadkowy, ale trzeba mieć na uwadze tę wewnętrzną sprzeczność. Warto jednak dodać, mimo że obowiązujące w Polsce przepisy nie są niezgodne z Europejską Kartą Samorządu Lokalnego, iż Karta nie przewiduje bezwzględnego obowiązku konsultacji „wszystkich projektów ustaw” z samorządem. Zgodnie bowiem z art. 4 ust. 6 Karty społeczności lokalne powinny być konsultowane o tyle, o ile jest to możliwe, we właściwym czasie i w odpowiednim trybie, w trakcie opracowywania planów oraz podejmowania decyzji we wszystkich sprawach bezpośrednio ich dotyczących.

Wdrożenie postulatu zawartego w Tezie nr 3 pt. „Przekształcenie Senatu RP w Izbę Samorządową", abstrahując od uprzedniej konieczności dokonania znacznych zmian w Konstytucji, sprowadziłoby Senat $w$ zasadzie do roli organu samorządowego ${ }^{34}$. Kompetencje Senatu zostały ściśle określone w Konstytucji. Na uwagę zasługuje przede wszystkim to, że Senat jako jeden z dwóch organów władzy ustawodawczej ma prawo do inicjatywy ustawodawczej i uczestniczy w uchwalaniu ustaw. Zatem widać tu wyraźny związek treści Tezy nr 3 z Tezą nr 5. Scedowanie na samorząd niektórych kompetencji władzy ustawodawczej wiązałoby się z przyjęciem rozwiązań ustrojowych, charakterystycznych dla państwa federalnego. Jednocześnie nic nie stoi na przeszkodzie, aby obecni przedstawiciele samorządu terytorialnego kandydowali w wyborach do Senatu. Ich kompetencje i wiarygodność będą oceniać obywatele poprzez głosowanie tak jak dzieje się to w odniesieniu do innych kandydatów do Senatu.

Teza nr 17 brzmi następująco: „Likwidacja urzędu wojewody. Pozostawienie władzy centralnej nadzoru nad legalnością działania jednostek samorządu terytorialnego". W jej lakonicznym uzasadnieniu wskazano jedynie, cyt. „Przekazanie wszystkich zadań dotyczących spraw publicznych w regionie samorządowi województwa". Treść Tezy nr 17 implikuje konieczność przypomnienia o roli i kompetencjach wojewody jako organu. Otóż należy podkreślić, że wojewoda jest przedstawicielem Rady Ministrów w województwie, zwierzchnikiem zespolonej w województwie administracji rządowej, organem nadzorczym nad działalnością jednostek samorządu terytorialnego i ich związków, organem wyższego stopnia w rozumieniu przepisów Kodeksu Postępowania Administracyjnego, reprezentantem Skarbu Państwa w zakresie i na zasadach określonych w odrębnych ustawach. Jako organ nadzoru nad działalnością jednostek samorządu terytorialnego wojewoda sprawuje kontrolę pod względem legalności, z zastrzeżeniem, że wojewoda kontroluje pod względem legalności, gospodarności oraz rzetelności wykonywanie przez organy samorządu zadań z zakresu administracji rządowej ${ }^{35}$. Do kompetencji wojewody jako monokratycznego organu administracji rządowej należą wszystkie sprawy z zakresu

34 Uzasadnienie Tezy nr 3 brzmi następująco: „Przedstawiciele samorządu terytorialnego, samorządów zawodowych oraz organizacji pozarządowych powinni uzyskać reprezentację na szczeblu najwyższych władz państwowych i uczestniczyć aktywnie w tworzeniu regulacji prawnych. Należy znieść monopol partii politycznych $w$ procesie stanowienia prawa w Polsce".

35 Szerzej: Z. Dobrowolski, Administracja publiczna w Polsce. Zarządzanie. Zarys problematyki, Wydawnictwo E-Studio, Kraków 2018, s. 60. 
administracji rządowej, o ile nie zostały one zastrzeżone na rzecz innych organów administracji rządowej ${ }^{36}$.

Jak słusznie zauważa A. Kiełbasiński, skoro kompetencje wojewodów wykraczają znacznie poza sprawowanie nadzoru nad samorządami, zawarty w Tezie nr 17 postulat Samorządnej Rzeczpospolitej ma w dużej mierze charakter polityczny ${ }^{37}$. Jednocześnie sam nadzór oparty o kryterium legalności oznacza, że działalność samorządu terytorialnego jest oceniana pod względem zgodności ze wszystkimi źródłami prawa o mocy powszechnie obowiązującej wraz z uwzględnieniem hierarchiczności aktów prawnych $^{38}$. Instytucja nadzoru nad samorządem terytorialnym jest jedną $z$ najistotniejszych gwarancji wykonywania przez samorząd zadań publicznych w ramach i na podstawie przepisów prawa, a przy tym nadzór determinuje rzeczywistą pozycję ustrojową samorządu, a także określa kierunek i zakres decentralizacji ${ }^{39}$. Zgodnie z unormowaniami, które zostały zawarte w art. 171 Konstytucji, organami uprawnionymi do pełnienia nadzoru nad samorządem terytorialnym jest nie tylko wojewoda, ale i: Sejm, Prezes Rady Ministrów i regionalne izby obrachunkowe ${ }^{40}$.

Przy analizie Tezy nr 17 pt. „Likwidacja urzędu wojewody” należy mieć też na uwadze jej związek z treścią Tezy nr 1, która brzmi następująco: „Pełne prawo wspólnoty samorządowej do samodzielnego decydowania o całokształcie spraw lokalnych". W jej uzasadnieniu wskazano, że „Jedynym organem nadzoru dla samorządów w kwestiach lokalnych są mieszkańcy". Pomimo że polskie regulacje prawne nie pozostają w sprzeczności z Europejską Kartą Samorządu Lokalnego, warto jednak zauważyć, że art. 8 Karty zakłada wprost istnienie kontroli administracyjnej nad działalnością społeczności lokalnych ${ }^{41}$.

Postulat zawarty w Tezie nr 14 dotyczy decentralizacji rozdziału funduszy unijnych. Zgodnie z treścią jej uzasadnienia powinna zostać wprowadzona „Maksymalna decentralizacja funduszy UE" oraz równocześnie zagwarantowana "Transparentność rozdziału dotacji rozwojowych na podstawie czytelnych kryteriów oraz jawnych arkuszy oceny projektów".

Obecnie za wdrażanie Funduszy Europejskich w Polsce odpowiada Minister Inwestycji i Rozwoju. Pomocniczym podmiotem Ministra jest Komitet do spraw Umowy Partnerstwa, który koordynuje działania realizowane przez wszystkie instytucje zajmujące

36 J. Zawisza, Rola administracji publicznej w kształtowaniu bezpieczeństwa państwa [w:] Funkcjonowanie administracji publicznej - historia i stan obecny, W. Brzęk, S. Ćmiel, K. Novikova (red.), Wydawnictwo Wyższej Szkoły Gospodarki Euroregionalnej im. Alcide De Gasperi w Józefowie, Józefów 2013, s. 71.

37 Por.: A. Kiełbasiński, 21 tez samorządowych nie zawsze dobrych dla biznesu https://wei.org.pl/article/21tez-samorzadowych-nie-zawsze-dobre-dla-biznesu/ (data dostępu: 11 stycznia 2020 r.).

38 G. Kościelniak, op. cit., s. 27.

39 Ibidem, s. 26.

40 Szerzej: M. Kowalczyk, Zarządzenie zastępcze wojewody jako środek nadzoru nad samorządem terytorialnym. Zagadnienia teoretyczne i praktyczne [w:] Samorządy w procesie decentralizacji władzy publicznej, M. Chrzanowski, J. Sobczak (red.), Wydawnictwo Muzyczne POLIHYMNIA, Lublin 2017, s. 184 i n.

41 Art. 8 Karty:

„1.Wszelka kontrola administracyjna społeczności lokalnych może być dokonywana wyłącznie w sposób oraz w przypadkach przewidzianych w Konstytucji lub w ustawie.

2.Wszelka kontrola administracyjna działalności społeczności lokalnych powinna w zasadzie mieć na celu jedynie zapewnienie przestrzegania prawa $i$ zasad konstytucyjnych. Kontrola administracyjna może jednakże obejmować kontrole celowości realizowaną przez organ wyższego szczebla w odniesieniu do zadań, których wykonanie zostało społecznościom lokalnym delegowane.

3.Kontrola administracyjna społeczności lokalnych powinna być sprawowana z zachowaniem proporcji między zakresem interwencji ze strony organu kontroli a znaczeniem interesów, które ma on chronić". 
się rozdzielaniem środków Unii Europejskiej oraz dba o to, żeby wdrażanie Funduszy Europejskich w Polsce wypełniało cele założone dla unijnej polityki spójności. Warto zauważyć, że w skład komitetu wchodzą m.in. przedstawiciele samorządów. Odpowiedzialność w zakresie rozdzielania i kontrolowania Funduszy jest podzielona pomiędzy wiele instytucji. Dla każdego z programów są wyznaczane instytucje zarządzające, które m.in. przygotowują procedury i kryteria wyboru projektów; sprawdzają czy dofinansowane projekty spełniają postawione przed nimi wymagania, a deklarowane przez beneficjentów wydatki zostały właściwie zrealizowane i zapłacone; oceniają i monitorują postępy w realizacji programu oraz certyfikują poniesione przez beneficjentów wydatki tzn. potwierdzają przed Komisją Europejską prawidłowość poniesionych przez beneficjentów wydatków i ich zgodność z prawem krajowym i unijnym. Instytucje zarządzające odpowiadają za realizację całego programu, ale swoje zadania często przekazują instytucjom pośredniczącym. Z kolei instytucje pośredniczące mogą przekazać część swoich zadań instytucjom wdrażającym. Dla każdego programu powoływany jest komitet monitorujący, w którego skład wchodzą m.in. przedstawiciele samorządów ${ }^{42}$. Zatem samorząd odgrywa znaczącą, aktywną rolę zarówno we wdrażaniu, jak i realizacji Funduszy Unijnych.

W nawiązaniu do postulatu zawartego w Tezie nr 14 należy mieć na względzie, że państwo jest dobrem wspólnym wszystkich obywateli, a istnieje duże prawdopodobieństwo, że tego rodzaju decentralizacja, która jest postulowana w treści Tezy, nie byłaby dokonana „w sposób przyjazny” dla obywateli, tj. nie uwzględniałaby odpowiedniej proporcji pomiędzy interesem danej społeczności lokalnej, a dobrem wszystkich obywateli.

Przy ocenie Tezy nr 14 trzaba mieć na uwadze postulat wyrównywania szans pomiędzy jednostkami. Interes ogólnonarodowy nie musi być zawsze tożsamy z interesem lokalnym. Wynika to z zasady równości w ujęciu materialnym, rozpatrywanej w kontekście zasady sprawiedliwości społecznej, a także zasady jednolitości państwa ${ }^{43}$.

\section{Uwagi końcowe}

Wprowadzenie w życie zmian przepisów prawnych postulowanych w Tezach nr 3 i $\mathrm{nr} 5$ niesie za sobą ryzyko zmian ustrojowych w Polsce zmierzających w kierunku państwa federalnego.

Abstrahując od landyzacji rozumianej jako stworzenie federalnego ustroju państwowego, która byłaby w oczywisty sposób sprzeczna z treścią art. 3 Konstytucji, należy podkreślić, że jakakolwiek koncepcja decentralizacji musiałaby zostać przeprowadzona w sposób przyjazny dla poszanowania „dobra wspólnego" wszystkich obywateli. Rozumianej w ten sposób decentralizacji nie uwzględnia treść Tez nr 1, nr 14 i $\mathrm{nr} 17$.

Obowiązujące przepisy dotyczące samorządu terytorialnego są zgodne z Konstytucją. Z kolei Konstytucja w całości spełnia przyjęte w Europejskiej Karcie Samorządu Lokalnego warunki dla samorządności terytorialnej. Zmian istniejących w tym zakresie regulacji prawnych nie można skutecznie dochodzić, powołując się na treść Karty.

Odnosząc się na marginesie do ustroju Niemiec warto dodać, że w Rozdziale II Umowy Poczdamskiej z dnia 2 sierpnia 1945 r. wprowadzono wymóg dokonania

\footnotetext{
42 https://www.funduszeeuropejskie.gov.pl/strony/o-funduszach/zasady-dzialania-funduszy/instytucje-isystem-realizacji-funduszy-europejskich/ (data dostępu: 11 stycznia 2019 r.).

43 Por.: G. Kościelniak, op. cit., s. 24.
} 
decentralizacji Niemiec zarówno w sensie gospodarczym oraz politycznym ${ }^{44}$. Miało to wpływ treść Ustawy Zasadniczej RFN (Grundgesetz) ${ }^{45}$. Uchwalona przez Radę Parlamentarną Ustawa Zasadnicza została zaakceptowana dnia 8 maja 1949 r. przez naczelnych komendantów zachodnich stref okupacyjnych. W Ustawie Zasadniczej zawarto zasady ustrojowe RFN, do których zaliczono m.in. federalizm. Decentralizacja RFN dokonana poprzez wprowadzenie ustroju federalnego miała przede wszystkim na celu osłabienie państwa. Ustawa Zasadnicza została ratyfikowana przez komendantów stref okupacyjnych oraz parlamenty krajowe, lecz nie spotkała się z akceptacją niemieckiego społeczeństwa ${ }^{46}$. Te okoliczności warto też mieć na uwadze przy ocenie koncepcji jednolitości ustrojowej państwa w porównaniu do ustroju federalnego.

\title{
Streszczenie:
}

W artykule zostały przeanalizowane kwestie związane z możliwością doprowadzenia do tzw. landyzacji Polski, rozumianej jako proces przekształcenia Polski w państwo federalne.

Rzeczpospolita Polska jest państwem jednolitym. Ustrój terytorialny Rzeczypospolitej Polskiej zapewnia decentralizację władzy publicznej, której nie należy postrzegać jako możliwość wprowadzenia ustroju federalnego.

Obowiązujące w Polsce przepisy dotyczące samorządu terytorialnego są w pełni zgodne z Europejską Kartą Samorządu Lokalnego.

Nie jest możliwe skuteczne domaganie się zmian ustrojowych w Polsce w oparciu o regulacje zawarte w Europejskiej Karcie Samorządu Lokalnego.

\section{Słowa kluczowe:}

decentralizacja, Europejska Karta Samorządu Terytorialnego, samorząd terytorialny, landyzacja, kontrola administracyjna

\section{Selected legal aspects of the so-called landisation of Poland}

\begin{abstract}
:
The paper focuses on the possibility of so-called landisation of Poland. Poland ratified The European Charter of Local Self-Government. The Charter provides that the principle of local self-government shall be recognised in domestic legislation and, where practicable, in the constitution. The Constitution of the Republic of Poland includes regulations regarding the local self-government. The basic powers and responsibilities of local authorities are prescribed in domestic law.

Poland shall be a unitary State. The territorial system of Poland shall ensure the decentralization of public power. The decentralization is not identical with the federalisation.
\end{abstract}

\section{Key words:}

decentralisation, European Charter of Local Self-Government, local authorities, landisation, administrative supervision

\section{Literatura:}

Antkowiak P., Decentralizacja władzy publicznej w Polsce, Środkowoeuropejskie Studia Polityczne, Nr 2, 2012, s. 155-174.

Buczyński K., Jaworski J., Sosnowski P., Bariery rozwoju samorządu terytorialnego w Polsce z perspektywy 25 lat jego funkcjonowania [w:] Bariery, wyzwania i perspektywy przekształceń samorządu terytorialnego w Polsce, S. Sagan, M. Sitek (red.), Wydawnictwo Wyższej Szkoły Gospodarki Euroregionalnej im. Alcide De

44 Tekst Umowy Poczdamskiej jest zamieszczony na stronie: http://avalon.law.yale.edu/20th_century/decade17.asp [data dostępu: 13 stycznia 2020 r.].

45 Por. K. Jedynakiewicz-Mróz, „Po owocach poznacie ich”. Niemieckie elity polityczne a powstanie RFN (1948-1949), Przegląd Nauk Historycznych, Nr 1, 2012, s. 75 i n.

46 P. Sobański, Roszczenia Polski wobec RFN w świetle doktryny niemieckiej, Wydawnictwo Wyższej Szkoły Pedagogiki i Administracji im. Mieszka I w Poznaniu, Poznań 2019, s. 186 i n.; R. Herbut, Systemy polityczne Republiki Federalnej Niemiec, Austrii i Szwajcarii (wybrane zagadnienia) [w:] Proces demokratyzacji Niemiec po 1945 roku. Wybrane zagadnienia, E. Stadtmüller-Wyborska (red.), Wydawnictwo Uniwersytetu Wrocławskiego, Wrocław 1992, s. 5. 
Wybrane aspekty prawne tzw. landyzacji Polski

Gasperi w Józefowie, Józefów 2016.

Buzek J., Samorządna Rzeczpospolita - 25 lat samorządu w Polsce, Ruch Prawniczy, Ekonomiczny i Socjologiczny, Zeszyt 3, 2015, s. 11-15.

Dąbrowski M., Domniemanie zgodności ustaw z Konstytucją Rzeczypospolitej Polskiej z 1997 roku, Katedra Prawa Konstytucyjnego na Wydziale Prawa i Administracji UWM Olsztyn, Olsztyn 2017.

Dobrowolski Z., Administracja publiczna w Polsce. Zarządzanie. Zarys problematyki, Wydawnictwo E-Studio, Kraków 2018.

Doliwa A., Konstytucjonalizacja osobowości prawnej jako podstawa współpracy międzynarodowej gmin, Białostockie Studia Prawnicze, Vol. 12, 2012, s. 209-218.

Herbut R., Systemy polityczne Republiki Federalnej Niemiec, Austrii i Szwajcarii (wybrane zagadnienia) [w:] Proces demokratyzacji Niemiec po 1945 roku. Wybrane zagadnienia, E. Stadtmüller-Wyborska (red.), Wydawnictwo Uniwersytetu Wrocławskiego, Wrocław 1992.

Jedynakiewicz-Mróz K., „Po owocach poznacie ich”. Niemieckie elity polityczne a powstanie RFN (19481949), Przegląd Nauk Historycznych, Nr 1, 2012, s. 63-84.

Kiełbasiński A., 21 tez samorządowych nie zawsze dobrych dla biznesu https://wei.org.pl/article/21-tezsamorzadowych-nie-zawsze-dobre-dla-biznesu/ (data dostępu: 11 stycznia 2020 r.).

Kieres L., Europejska karta samorządu lokalnego w orzecznictwie Trybunału Konstytucyjnego, Ruch Prawniczy, Ekonomiczny i Socjologiczny, Zeszyt 3, 2015, s. 79-99.

Kilper H., Lhotta R., Föderalismus in der Bundesrepublik Deutschland: Eine Einführung, Springer Verlag, Wiesbaden 1996.

Korczak J., Współdziałanie organów administracji rządowej i samorządowej w stanach nadzwyczajnych, LEX Nr 313966/2.

Kościelniak G., Zmiany społeczne, gospodarcze i kulturowe w erze ponowoczesnej a ustrojowa przyszłość instytucji samorządu terytorialnego w Polsce, Państwo i Społeczeństwo, Nr 3, 2012, s. 17-39.

Kowalczyk M., Zarządzenie zastępcze wojewody jako środek nadzoru nad samorządem terytorialnym. Zagadnienia teoretyczne i praktyczne [w:] Samorządy w procesie decentralizacji władzy publicznej, M. Chrzanowski, J. Sobczak (red.), Wydawnictwo Muzyczne POLIHYMNIA, Lublin 2017.

Lewandowski P., Tylko u nas! To się dzieje. Trwa pełzające rozbicie dzielnicowe https://polskaniepodlegla.pl/opinie/item/20467-tylko-u-nas-to-sie-dzieje-trwa-pelzajace-rozbicie-dzielnicowe (data dostępu: 5 stycznia 2020 r.).

Litwin T., Pojęcie „przedstawiciela Narodu” w świetle art. 4 ust. 2 Konstytucji RP z 1997 r., Horyzonty Polityki, Vol. 9, s. 11-31.

Lorz R. A., Interorganrespekt im Verfassungsrecht: Funktionenzuordnung, Rücksichtnahmegebote und Kooperationsverpflichthungen: eine rechtsvergleichende Analyse anhand der Verfassungssysteme der Bundesrepublik Deutschland, der Europäischen Union und der Vereinigten Staaten, Mohr Siebeck, Tübingen 2001.

Łączkowski W., Trójpodział władz a dobro wspólne, Lex nr 339140/1.

Mączyński M., Reforma ustroju samorządu terytorialnego: uwarunkowania, możliwości i konsekwencje zwiększenia samodzielności JST [w:] Sprawne państwo. Propozycje zmian w funkcjonowaniu jednostek samorządu terytorialnego w Polsce, P. Kopyciński (red.), Uniwersytet Ekonomiczny w Krakowie, Kraków 2015.

Patyra S., Samorząd terytorialny jako czynnik wzmacniający zasadę dobra wspólnego, Ruch Prawniczy, Ekonomiczny i Socjologiczny, Zeszyt 1, 2018, s. 231-239.

Patyra S., Zakres dopuszczalnej ingerencji władzy centralnej $w$ sferę funkcjonowania samorządu terytorialnego w Polsce - refleksje aksjologiczne [w:] Samorządy w procesie decentralizacji władzy publicznej, M. Chrzanowski, J. Sobczak (red.), Wydawnictwo Muzyczne POLIHYMNIA, Lublin 2017, s. 26.

Rachoń M., Więcej kasy w ręce ludzi Platformy, nawet kosztem likwidacji państwa https://niezalezna.pl/283355-wiecej-kasy-w-rece-ludzi-platformy-nawet-kosztem-likwidacji-panstwa (data dostępu: 7 stycznia 2020 r.).

Radziewicz P., Decentralizacja jako pojęcie prawne, Kwartalnik Prawa Publicznego, Nr 1-2, 2015, s. 7-36.

Sobański P., Roszczenia Polski wobec RFN w świetle doktryny niemieckiej, Wydawnictwo Wyższej Szkoły Pedagogiki i Administracji im. Mieszka I w Poznaniu, Poznań 2019.

Zawisza J., Rola administracji publicznej w kształtowaniu bezpieczeństwa państwa [w:] Funkcjonowanie administracji publicznej - historia i stan obecny, W. Brzęk, S. Ćmiel, K. Novikova (red.), Wydawnictwo Wyższej Szkoły Gospodarki Euroregionalnej im. Alcide De Gasperi w Józefowie, Józefów 2013. 